\title{
Research on Non-autoclaved Fly Ash Lightweight Wall Block with Material Properties
}

\author{
Jie ZHANG \\ Yangzhou College of Industrial Technology Department of Chemical Engineering, Yangzhou \\ 225127, Jiangsu \\ zjqnlm@163.com
}

Keywords: Industrial Waste, Fly Ash, Non-autoclaved, Activator, Block.

\begin{abstract}
Non-autoclaved fly ash lightweight wall block with industrial waste fly ash as main raw material enhance the activity of fly ash by mechanical activation at the normal temperature and pressure, and through adding activator sodium silicate, gypsum, sodium sulfate for chemical activation. Experiments show that the effect of complex excitation is better than single excitation. The quality and quantity of the foaming agent have a direct impact on compressive strength of block. It is simple equipment and small investment to reduce environmental pollution of industrial waste fly ash generated and to achieve waste utilization by foaming fly ash block at the normal temperature and pressure.

Non-autoclaved fly ash lightweight wall block mainly utilize potentially reactive of the industrial waste fly ash from power plant. Fly ash contains aluminum silicate massive vitreous, the vitreous stored chemical energy high after calcination, and this is the source of the activity of fly ash. But the most of the volcano ash activity is potential and its active play very slowly because of the high degree of polymerization of [SiO4]4- components, compact structure, stable chemical property. At present, the method of fly ash activation is mechanical activation and mechanical activation combined with chemical activation. The author fully excite the activity of fly ash by using the foaming agent, and test to produce the non-autoclaved fly ash lightweight wall block on account of the experimental study and theoretical analysis in the fly ash cement lime system [1].
\end{abstract}

\section{Main Raw Materials}

Fly ash, P•O32.5R ordinary portland cement, Lime, Foaming agents (self-made).

\section{Experiment}

The ratio of main raw materials of non-autoclaved fly ash light wall block is $\mathrm{m}$ (fly ash): $\mathrm{m}$ (cement): $\mathrm{m}($ lime $)=50: 40: 10$ [2].Through the test, fly ash and sulfate is mechanical activated and it stimulated better in an alkaline environment and to. The following is using alkaline and sulfate activator for the test based on mechanical activation.

\section{Mechanical Activation}

By fine grinding process of crushing posterior vitreous layer of packages, the surface becomes rough or crack and increases the surface in the volcano ash effect. It is better for permeability of the $\mathrm{Ca}^{2+}$ ion and dissolution of vitreous silica, aluminum. From the micro perspective, fine grinding can promote fly ash particles native lattice to defect, destruct and cut off $\mathrm{Si}-\mathrm{O}$ and $\mathrm{A} 1-\mathrm{O}$ bond in the network, it also generates high active atomic groups and charged cross-section to improve the irregular structure and degree. From the energy perspective, fine grinding of fly ash can improve the chemical energy, increase its chemical instability, and then increase the activity. The same fly ash is fine grinded (uses the ball mill grinding $15 \mathrm{~min}$, speed $110 \mathrm{r} / \mathrm{min}$ ). It is made to the block according to the ratio of $\mathrm{m}$ (fly ash):m (cement): $\mathrm{m}$ (lime) $=50: 40: 10$, by fixing agent, foaming agent, the ratio of dosage and water cement, then studied fine grinding effect on the compressive strength showed in table 1. 
Tab.1 The effect of fly ash on the compressive strength of the block before and after fine grinding (28 days)

\begin{tabular}{cccc}
\hline & Ratio/\% & Bulk densit $/ \mathrm{kg} / \mathrm{m}^{3}$ & Compressive strength/Mpa \\
\hline Original fly ash & 50 & 680 & 2.32 \\
\hline Finely ground fly ash & 50 & 680 & 2.63 \\
\hline
\end{tabular}

Table 1 shows that after it has been ground, improving compressive strength of specimen blocks.

\section{Excitation Effect of $\mathrm{Na2SiO3}$}

In the fly ash and $\mathrm{Ca}(\mathrm{OH}) 2$, cement mixture, the hydrolysis of $\mathrm{Na} 2 \mathrm{SiO}$ to $\mathrm{NaOH}$ increase the $\mathrm{OH}-$ ion[2], then conduce corrosion of vitreous. There are two effects of generated $\mathrm{NaOH}$ :

(1)The neutralization reaction of surface silanol groups:

$$
-\mathrm{O}-\mathrm{Si}-\mathrm{OH}+\mathrm{NaOH} \rightarrow-\mathrm{O}-\mathrm{Si}-\mathrm{ONa}+\mathrm{H}_{2} \mathrm{O}
$$

The acid-base reactions that are repeated in the vitreous surface are the base of fly ash vitreous surface erosion process.

(2)The damage of internal silicon hydride key gradually cause the structure disintegration of the $\left[(\mathrm{Si}, \mathrm{Al}) \mathrm{O}_{4}\right]_{\mathrm{n}}$ :

$$
-\mathrm{O}-\mathrm{Si}-\mathrm{OSi}-+2 \mathrm{NaOH} \rightarrow 2(-\mathrm{O}-\mathrm{Si}-\mathrm{ONa})+\mathrm{H}_{2} \mathrm{O}
$$

$\mathrm{Na}^{+}$is replaced by $\mathrm{Ca}^{2+}$ as $-\mathrm{O}-\mathrm{Si}-\mathrm{ONa}$ was soluble. Later generated hydrated calcium silicate is precipitated. In this way, $\mathrm{Ca}(\mathrm{OH})_{2}$ is constantly dissolved to $\mathrm{Ca}^{2+}$ and $\mathrm{OH}^{-}$ions. $\mathrm{OH}^{-}$that stayed in the liquid phase maintained a high $\mathrm{pH}$. The replaced $\mathrm{Na}^{+}$by $\mathrm{Ca}^{2+}$ can be used repeatedly, so that the reaction is constant. Therefore, $\mathrm{Na}_{2} \mathrm{SiO}_{3}$ accelerate the reaction of fly ash and $\mathrm{Ca}(\mathrm{OH})_{2}$.

In addition, the hydrolysis of $\mathrm{Na}_{2} \mathrm{SiO}_{3}$ also generated hydrated silica gel, the gel can react with $\mathrm{Ca}^{2+}$ to form C-S-H gel, and also accelerated the fly ash and $\mathrm{Ca}(\mathrm{OH})_{2}$ response.

According to $\mathrm{m}$ (fly ash): $\mathrm{m}$ (cement): $\mathrm{m}$ (lime) ratio of raw materials $=50: 40: 10$, fixed foam agent and dosage, water cement ratio, the effect of different dosage of $\mathrm{Na}_{2} \mathrm{SiO}_{3}$ on the compressive strength of block is studied. The results after $28 \mathrm{~d}$ were shown in table 2 .

Tab.2 The effect of different dosage of $\mathrm{Na}_{2} \mathrm{SiO}_{3}$ on the compressive strength of the block (28 days)

\begin{tabular}{cccc}
\hline No. & $\mathrm{Na}_{2} \mathrm{SiO}_{3} / \%$ & Bulk density $/ \mathrm{kg} / \mathrm{m}^{3}$ & $\begin{array}{c}\text { Compressive } \\
\text { strength/Mpa }\end{array}$ \\
\hline 1 & 0 & 680 & 2.63 \\
2 & 0.4 & 680 & 2.97 \\
3 & 0.5 & 680 & 2.98 \\
4 & 0.6 & 680 & 3.01 \\
5 & 0.7 & 680 & 3.02 \\
6 & 0.8 & 680 & 3.03 \\
7 & 0.9 & 680 & 3.03 \\
\hline
\end{tabular}

From table 2, we can see that it is beneficial to improve the compressive strength of block by adding some $\mathrm{Na}_{2} \mathrm{SiO}_{3}$. When the dosage of $\mathrm{Na}_{2} \mathrm{SiO}_{3}$ increased from 0 to $0.4 \%$, the compressive strength of block increase considerably, while continuing to increase the $\mathrm{Na}_{2} \mathrm{SiO}_{3}$, the compressive strength of block did not changed obviously.

\section{Excitation Effect of Gypsum}

The excitation effect of gypsum is reflected in two aspects: One is that it increases the reaction rate; the other is that it reacts with material in the system to generate cement-gel hydrates. When 
flly ash-cement-lime system was added to water, the first lime reacted with water to generate $\mathrm{Ca}(\mathrm{OH})_{2}$. Meanwhile, the active component $\mathrm{SiO}_{2}$ and $\mathrm{Al}_{2} \mathrm{O}_{3}$ in fly ash were dissolved in water and then reacted with $\mathrm{Ca}(\mathrm{OH})_{2}$ to generate C-S-H gel and hydrated aluminate. Previous reaction is fast, and it accompanied volume expansion and it is hard to generate $\mathrm{Ca}(\mathrm{OH})_{2}$. After the active component in fly ash reacted with $\mathrm{Ca}(\mathrm{OH})_{2}$, it converted to water hardness hydration. The generated C-S-H gels were wrapped in particle surface of fly ash and it slowed hydration, so the slow growth of strength was in it. When adding gypsum as excitant, dissolved $\mathrm{Al}_{2} \mathrm{O}_{3}$ from gypsum and fly ash reacted to generate ettringite in the presence of $\mathrm{CaO}$.The growth of crystal ettringite induced expansion of slurry. The fly ash particles paced by hydration products re-exposed the new surface, and accelerated the activation of fly ash; on the other hand, $\mathrm{SO}_{4}{ }^{2-}$ added into gypsum slurry will penetrate into the $\mathrm{C}-\mathrm{S}-\mathrm{H}$ gel. It changed the permeability of $\mathrm{C}-\mathrm{S}-\mathrm{H}$ gel, which accelerated the pozzolanic reaction of fly ash.

Table 3 is the effect of different gypsum on compressive strength of block. It is seen from table 3 that the proper amount of gypsum will increase the strength, and excessive gypsum will make strength decline. This is because that gypsum delay digestion of lime obviously, and slow thickening speed of the slurry. Therefore, gypsum dosage should be controlled within 5\%. The plaster dosage is $4 \%$ in this test.

Tab.3 The effect of the block different dosage of $\mathrm{Na}_{2} \mathrm{SiO}_{3} \mathrm{CaSO}_{4}$ on the compressive strength of the bloclk (28 days)

\begin{tabular}{cccc}
\hline No. & Gypsum $/ \%$ & Bulk density $/ \mathrm{kg} / \mathrm{m}^{3}$ & $\begin{array}{c}\text { Compressive } \\
\text { strength/Mpa }\end{array}$ \\
\hline 1 & 0 & 680 & 2.63 \\
2 & 1 & 680 & 2.71 \\
3 & 2 & 680 & 2.83 \\
4 & 3 & 680 & 2.87 \\
5 & 4 & 680 & 2.91 \\
6 & 5 & 680 & 2.81 \\
7 & 6 & 680 & 2.67 \\
\hline
\end{tabular}

\section{Excitation Effect of Sodium Sulfate}

The mainly effect of sodium sulfate to excite the activity of fly ash is $\mathrm{SO}_{4}{ }^{2-}$, in the role of $\mathrm{Ca}^{2+}$, and the active $\mathrm{A}_{2} \mathrm{O}_{3}$ dissolved in the liquid phase carry on hydration reaction and generate hydrated calcium aluminate sulfate AFt that is ettringite. Reaction is:

$$
\mathrm{A}_{2} \mathrm{O}_{3} \text { (Activity) }+\mathrm{Ca}^{2+}+\mathrm{OH}^{-}+\mathrm{SO}_{4}{ }^{2-} \rightarrow 3 \mathrm{CaO} \cdot \mathrm{A}_{2} \mathrm{O}_{3} \cdot 3 \mathrm{CaSO}_{4} \cdot 32 \mathrm{H}_{2} \mathrm{O}
$$

Part of the hydrated calcium aluminate can react with gypsum to generater AFt:

$$
3 \mathrm{CaO} \cdot \mathrm{Al}_{2} \mathrm{O}_{3} \cdot 6 \mathrm{H}_{2} \mathrm{O}+3\left(\mathrm{CaSO}_{4} \cdot 2 \mathrm{H}_{2} \mathrm{O}\right)+2 \mathrm{H}_{2} \mathrm{O} \rightarrow 3 \mathrm{CaO} \cdot \mathrm{A}_{2} \mathrm{O}_{3} \cdot 3 \mathrm{CaSO}_{4} \cdot 32 \mathrm{H}_{2} \mathrm{O}
$$

The normally used sulfate activator is mirabilite and gypsum. Excitation effect of $\mathrm{Na}_{2} \mathrm{SO}_{4}$ is better than that of $\mathrm{CaSO}_{4}$. Firstly, $\mathrm{Na}_{2} \mathrm{SO}_{4}$ is diffluent in water, and can react with $\mathrm{Ca}(\mathrm{OH})_{2}$ in the system to generate highly-dispersed $\mathrm{CaSO}_{4}$. Secondly, it can enhance system alkalinity. Therefore, excitation of $\mathrm{Na}_{2} \mathrm{SO}_{4}$ is actually a double excitation of sulfate and alkali. Sodium sulfate activator can not exceed a certain range. Experiments show that, when $\mathrm{Na}_{2} \mathrm{SO}_{4}$ dosage is higher than $3 \%$, it will cause the "Pan-cream" phenomenon. Moreover, due to slow dissolution of the activity $\mathrm{A}_{2} \mathrm{O}_{3}$ in fly ash, and later dissolved active $\mathrm{A}_{2} \mathrm{O}_{3}$ also can produce $\mathrm{AFt}$, the activity of $\mathrm{A}_{2} \mathrm{O}_{3}$ later leaching 
will generate AFt. AFt and $\mathrm{CaSO}_{4}$ itself has expanded. If too much, block internally will generate the micro-cracks, and lead to late strength decreasing. The plaster dosage of sodium sulfate is $2 \%$ in this test.

\section{Excitation effect of compound activator}

Compound activator combined activator function of $\mathrm{Na}_{2} \mathrm{SiO}_{3}$ and $\mathrm{Na}_{2} \mathrm{SO}_{4}$, Experiments show that Compound activator has a greater effect on the compressive strength of block than single use of an activator. The results are shown in table 4.

Tab.4 The effect of different activating agents on block intensities

\begin{tabular}{ccc}
\hline & Bulk density/kg/m & Compressive strength/Mpa \\
\hline $\mathrm{No}^{3}$ activator & 680 & 2.63 \\
$\mathrm{Na}_{2} \mathrm{SiO}_{3}$ & 680 & 2.98 \\
$\mathrm{Gypsum}$ & 680 & 2.87 \\
$\mathrm{Na}_{2} \mathrm{SO}_{4}$ & 680 & 3.06 \\
Composite & 680 & 3.46 \\
activator & &
\end{tabular}

Simply using an activator can not significantly increase the compressive strength of blocks. We synthesize chemical excitation and mechanical excitation, and use the Compound activator. The excitation effect becomes more obvious [4].

\section{Affect on the Quality and Quantity of the Foaming Agent}

Foaming agent directly affects the quality of block. This test uses the self-made polymer modified rosin soap foam [3], when used about 20 times by adding water, stirring whipped. Stirring speed is $600 \mathrm{r} / \mathrm{min}$. Mixing time is $2 \mathrm{~min}$, and foam height is about $15 \mathrm{~cm}$. We add the foam to the block, Firstly, it reduces the weight of the block; secondly, it improves the insulation ability of the block. Adding foaming agent will make the compressive strength of block and bulk density contradictory. With the increase of foam agent, block in the "skeleton" weakens, and compressive strength of the block decreases. Under the premise of the certainly compressive strength in the brick, this experiment achieves the light quality and the heat preservation, namely the artificial brick with compressive strength and the bulk specific gravity coordinate. As synthesize the requests of compressive strength and bulk density of block, the foam volume added is twice to slurry volume.

\section{Production Crafts}

Firstly, the fly ash fine is grinded, namely mechanical activation. Because with less complex activator, the fine grinded fly ash and activator compound and some water are mixed, and aged for 2 $\mathrm{d}$ to excite the activity of fly ash fully. Then we add raw materials, and mix into slurry at a certain ratio, then add the foaming agent, mould, strip, and finally moisture conserve for $14 \mathrm{~d}$.

\section{Conclusion}

(1) After determining proportion of fly ash, cement, lime, and determine, we use the best chemical activators and dosage to fully excite the activity of fly ash; and determine the foam content to coordinate block the bulk density and compressive strength.

(2) Chemical excitation and mechanical excitation reinforce mutually, and it is advantageous to improve the activity of fly ash.

(3) Effect of compound activator is better than a single activator. 
(4) Fly ash bricks are producted at the normal temperature and pressure without steam conservation. It save energy, and make full use of industrial waste.

\section{References}

[1]Zhang Jie. Flyash brick wall of foam developed at room temperature [J]. Portland Bulletin, 2006, 25 (3): 200-203

[2]Wen $\mathrm{Zi}$ Yun alkali - silica aggregate reaction of the chemical mechanism of silicate, 1994, 17 (6): 596-603

[3]Zhang Jie, Zhang $\mathrm{Hu}$, remember, Liang Huifeng, etc. roof foam insulation board [J]. New building materials, 2002, 8: 33 .

[4]Zhang Jie, Zhu Quan. Roof insulation board of water [J]. New Building Materials, 2008, 1:74-76. 